\title{
Steroid conversion with CYP106A2 - production of pharmaceutically interesting DHEA metabolites
}

\author{
Daniela Schmitz ${ }^{1}$, Josef Zapp ${ }^{2}$ and Rita Bernhardt ${ }^{1 *}$
}

\begin{abstract}
Background: Steroids are lipophilic compounds with a gonane skeleton and play an important role in higher organisms. Due to different functionalizations - mainly hydroxylations - at the steroid molecule, they vary highly in their mode of action. The pharmaceutical industry is, therefore, interested in hydroxysteroids as therapeutic agents. The insertion of hydroxyl groups into a steroid core, however, is hardly accomplishable by classical chemical means; that is because microbial steroid hydroxylations are investigated and applied since decades. CYP106A2 is a cytochrome P450 monooxygenase from Bacillus megaterium ATCC 13368, which was first described in the late 1970s and which is capable to hydroxylate a variety of 3-oxo-delta4 steroids at position 15beta. CYP106A2 is a soluble protein, easy to express and to purify in high amounts, which makes this enzyme an interesting target for biotechnological purposes.

Results: In this work a focused steroid library was screened in vitro for new CYP106A2 substrates using a reconstituted enzyme assay. Five new substrates were identified, including dehydroepiandrosterone and pregnenolone. NMR-spectroscopy revealed that both steroids are mainly hydroxylated at position 7 beta. In order to establish a biotechnological system for the preparative scale production of 7 beta-hydroxylated dehydroepiandrosterone, whole-cell conversions with growing and resting cells of B. megaterium ATCC1336 the native host of CYP1062 and also with resting cells of a recombinant B. megaterium MS941 strain overexpressing CYP106A2 have been conducted and conversion rates of $400 \mathrm{muM} / \mathrm{h}(115 \mathrm{mg} / \mathrm{l} / \mathrm{h})$ were obtained. Using the B. megaterium MS941 overexpression strain, the selectivity of the reaction was improved from 0.7 to 0.9 for 7 beta-OH-DHEA.

Conclusions: In this work we describe CYP106A2 for the first time as a regio-selective hydroxylase for 3-hydroxy-delta5 steroids. DHEA was shown to be converted to 7beta-OH-DHEA which is a highly interesting human metabolite, supposed to act as neuroprotective, anti-inflammatory and immune-modulatory agent. Optimization of the whole-cell system using different B. megaterium strains lead to a conversion of DHEA with B. megaterium showing high selectivity and conversion rates and displaying a volumetric yield of $103 \mathrm{mg} / \mathrm{l} / \mathrm{h}$ 7beta-OH-DHEA.
\end{abstract}

Keywords: Cytochrome P450, Steroid hydroxylase, Bacillus megaterium, Whole-cell conversion, Dehydroepiandrosterone, Microbial, CYP106A2

\section{Background}

Cytochrome P450 enzymes (P450s) are heme-containing monooxygenases showing an eponymous absorbance maximum at $450 \mathrm{~nm}$ of the reduced CO-complex [1]. P450s compose one of the largest and oldest gene families with representatives in all kingdoms of life [2] were they are involved in the biosynthesis and tailoring of natural products like sterols, terpenoids, polyketides, alkaloids, and

\footnotetext{
* Correspondence: ritabern@mx.uni-saarland.de

'Department of Biochemistry, Saarland University, Campus B2 2

Saarbruecken 66123, Germany

Full list of author information is available at the end of the article
}

others [3]. In humans, P450s are, for instance, involved in the biosynthesis of cholesterol, steroid hormones, vitamin D, eicosanoids and prostaglandins; furthermore, they are key enzymes in the biotransformation of xenobiotics in the liver. Cytochrome P450 enzymes belong to the group of external monooxygenases, catalyzing the insertion of one atom of oxygen into a substrate and the concomitant reduction of the second oxygen atom to water. On the basis of this mechanism P450s are able to perform a variety of reactions including $\mathrm{N}$-oxidations, $\mathrm{N}-, \mathrm{O}-$, and $\mathrm{S}-$ dealkylations, sulfoxidations, epoxidations, peroxidations, dehalogenations, $\mathrm{N}$-oxide reductions, and even $\mathrm{C}-\mathrm{C}$ bond 
cleavage $[4,5]$. Their broad substrate range and reaction spectrum make cytochrome $\mathrm{P} 450$ enzymes interesting candidates for industrial purposes. The ability of P450 to introduce hydroxyl groups into non-activated carbon bonds is unique; this spin-forbidden reaction is only scarcely feasible in a regioselective manner by classical chemical means. Hydroxylations are of special interest to pharmaceutical industry, because the insertion of only one hydroxyl group into a certain substrate can dramatically influence its bioavailability, bioactivity or solubility. One famous example is the P450-dependent formation of pravastatin from compactin. Pravastatin exhibits a considerable increased inhibitory activity against the HMGCoA reductase, the key enzyme in cholesterol biosynthesis [6]. Thus, the assembly of pravastatin using a bioconversion process developed by Sankyo (present DaiichiSankyo) represents a successful industrial application of P450s [7]. Another interesting application of P450s is the production of human metabolites either of endogenous origin, like hydroxysteroids, or hydroxylated xenobiotics such as drugs. However, the use of cytochromes P450 is to date mostly limited to the production of high-value fine chemicals or pharmaceutically interesting human metabolites for analytical purposes. At the moment, the productivity of P450 reactions is often not sufficient for the bulk production of chemicals, due to several limitations like their multi-component character, their low stability under process conditions and the consumption of cost-intensive co-factors (NADPH, NADH) in stoichiometric amounts [7-9]. Furthermore, human cytochrome P450s are membrane bound proteins, which are difficult to express and to purify. To overcome at least some of these drawbacks, whole-cell systems are the method of choice to accomplish $\mathrm{P} 450$ reactions $[8,10]$.

Steroids are one of the most interesting classes of P450 substrates for pharmaceutical and biotechnological purposes. These terpenoic compounds with a gonane skeleton play a vital role in the human metabolism. Steroids are responsible for the maintenance of blood-pressure and homeostasis, sex development and stress response. Imbalances in the steroid level can have severe pathological effects [11]. Estrogens, for instance, which are produced in adipose tissue, are involved in the formation of postmenopausal breast cancer [12]. From a biotechnological point of view, bacterial steroid hydroxylases have the advantage, in contrast to their eukaryotic counterparts, that they are soluble proteins, which facilitates their recombinant expression and purification. CYP106A2 from Bacillus megaterium ATCC13368 is one of only few cloned bacterial steroid hydroxylases which has been investigated since decades and emerged as a potent biocatalyst for the preparative scale production of hydroxysteroids [13]. Most substrates of CYP106A2 are 3-oxo- $\Delta^{4}$ steroids, which are hydroxylated mainly in the $15 \beta$-position [14-16]. So far, conversions of 3-hydroxy- $\Delta^{5}$, ring-reduced or aromatic steroids with CYP106A2 have not been described. Recent studies conducted with this enzyme showed, however, that it is also capable to hydroxylate di- and triterpenoids with diverse backbones. Bleif et al. identified the diterpene resin acid abietic acid and the tetracyclic triterpene 11-keto$\beta$-boswellic acid as substrates of CYP106A2 [17,18]. Screening of a natural product library further broadened the substrate spectrum of this enzyme, with the identification of the less polar triterpenoids dipterocarpol and betuline as substrates [19]. Interestingly, the aforementioned substrates lack a 3-oxo- $\Delta^{4}$ motif and dipterocarpol, betuline, and abietic acid do even not contain any keto-en moiety in their structure, which encouraged us to investigate whether CYP106A2 is yet able to hydroxylate non-3oxo- $\Delta^{4}$ steroids. Screening of a focused library consisting of 11 steroidal compounds, among them 3-hydroxy- $\Delta^{5}$, A-ring-reduced, aromatic and D-ring-modified steroids revealed novel non-3-oxo- $\Delta^{4}$ steroid substrates for CYP 106A2, among them dehydroepiandrosterone (DHEA) and pregnenolone (PREG). NMR analysis showed that both DHEA and PREG were hydroxylated preferably at position $7 \beta$. DHEA was also hydroxylated at position $7 \alpha$, but to a minor extend. 7-oxygenated steroids and sterols are widespread in mammals, birds, fish and plants [20]. In humans, DHEA and PREG are $7 \alpha$-hydroxylated in various tissues by different cytochrome P450 enzymes including liver, intestine, and brain. However, there is no mammalian enzyme described yet which catalyzes the formation of $7 \beta-\mathrm{OH}-\mathrm{DHEA}$. Experimental and clinical data indicated that hydroxylated DHEA derivatives are bioactive human metabolites, responsible for at least some of the DHEA actions in the body, like neuroprotective, anti-inflammatory and anti-proliferative effects [21,22]. For these reasons we established in this work a competitive P450 whole-cell process for the production of $7 \beta$-hydroxylated DHEA.

\section{Results and discussion}

\section{Screening of a focused steroid library}

Most CYP106A2 substrates contain a 3 -oxo- $\Delta^{4}$-moiety and it was assumed for a long time that this motif is a prerequisite for conversions using this enzyme (Table 1). However, recent findings revealed that CYP106A2 indeed is able to convert compounds lacking such a motif $[17,18,23]$, which encouraged us to investigate whether CYP106A2 is also able to catalyze the hydroxylation of steroids lacking the 3-oxo- $\Delta^{4}$-moiety. Therefore, a focused steroid library, consisting of 11 non-3-oxo- $\Delta^{4}$ steroids was screened in an in vitro enzyme assay. The mitochondrial electron transfer system from bovine adrenals was used to reconstitute the CYP106A2 enzyme system, because the bovine electron transfer proteins are well established as efficient electron suppliers for CYP106A2 and other bacterial P450s [24,25]. 
Table 1 Steroids tested for conversion with CYP106A2

\begin{tabular}{|c|c|c|}
\hline Steroid & $\begin{array}{l}\text { Product formation: main } \\
\text { hydroxylation position } \\
\text { (minor products if known) }\end{array}$ & $\begin{array}{c}\text { Induction of } \\
\text { high-spin } \\
\text { shift }\end{array}$ \\
\hline \multicolumn{3}{|l|}{ 3-oxo- $\triangle^{4}$ type steroids } \\
\hline Deoxycorticosterone $e^{a}$ & $15 \beta$ & Yes \\
\hline $\begin{array}{l}\text { 6-Fluoric-methyl- } \\
\text { deoxycorticosterone }\end{array}$ & $15 \beta$ & Yes \\
\hline Corticosterone $^{a}$ & $15 \beta$ & No \\
\hline Cholestenone $^{c}$ & $15 \beta$ & Yes \\
\hline Progesterone $e^{a}$ & $15 \beta(11 a, 6 \beta, 9 a)$ & No \\
\hline 17a-Hydroxyprogesterone $e^{a}$ & $15 \beta$ & No \\
\hline 20a-Dihydroprogesterone $e^{a}$ & $15 \beta$ & No \\
\hline Androstenedione $e^{a}$ & $15 \beta$ & Yes \\
\hline Testosterone $^{a}$ & $15 \beta$ & Yes \\
\hline \multicolumn{3}{|l|}{ 3-hydroxy- $\Delta^{5}$-steroids } \\
\hline Dehydroepiandrosterone $^{\dagger}$ & $7 \beta(7 a)$ & No \\
\hline Pregnenolone $^{\dagger}$ & $7 \beta$ & No \\
\hline Stigmasterol $^{\dagger}$ & No & No \\
\hline Cholesterol $^{\dagger}$ & No & No \\
\hline \multicolumn{3}{|l|}{ Other steroids } \\
\hline Estradiol $^{+}$ & No & No \\
\hline Estrone $^{\dagger}$ & No & No \\
\hline $\mathrm{Cis} /$ Trans-androsterone $^{\dagger}$ & No & No \\
\hline Digitoxigenin $^{\dagger}$ & n.d & No \\
\hline Prednisone $^{\dagger}$ & n.d. & No \\
\hline Dexamethasone $^{\dagger}$ & n.d & No \\
\hline
\end{tabular}

no $=$ no conversion $/$ no spin shift, n.d. = hydroxylation position not determined. ${ }^{\dagger}=$ tested in this work.

${ }^{\mathrm{a}}[14]^{\mathrm{b}}[44]^{\mathrm{c}}[26]$.

To investigate the catalytic activity of CYP106A2 towards 3-hydroxy- $\Delta^{5}$ steroids, we performed in vitro reactions with dehydroepiandrosterone, pregnenolone, cis-androsterone, trans-androsterone, cholesterol, and stigmasterine. Estrone, estradiol, as well as prednisone and dexamethasone were tested as examples for aromatic and ring-reduced steroids. Additionally, we chose digitoxigenin, the steroidal aglycone of the cardio-active glycoside as a potential substrate with D-ring modification. TLC and HPLC analysis were performed and steroid conversion has been observed for five out of eleven substances tested (Table 1). Reaction products were detected using dehydroepiandrosterone (DHEA), pregnenolone (PREG), dexamethasone, prednisone, and digitoxigenin as substrates (Scheme 1). According to these results, it can be stated that the 3-oxo- $\Delta^{4}$ moiety is not crucial for steroid conversion with CYP106A2. However, estrone, estradiol, stigmasterol, and cholesterol were not hydroxylated by CYP106A2. We assume that the lower flexibility of the aromatic A-ring of the three steroids hinders binding and hydroxylation. Why cholesterol and stigmasterol are not converted by CYP106A2 cannot be explained at this point. The size of these steroids should not be the problem because CYP106A2 is able to hydroxylate cholestenone and dipterocarpol which are of similar size. Considering that cholestenone is the 3-oxo- $\Delta^{4}$ counterpart of cholesterol, it can be assumed that the 3-oxo- $\Delta^{4}$ motif present in this case plays a crucial role [26]. Table 1 contains an overview about all steroids which were tested as substrates for CYP106A2.

NMR spectroscopy was applied to resolve the structure of the newly identified CYP106A2 reaction products. To obtain the required amounts (mg), B. megaterium ATCC13368 was used for preparative scale whole-cell conversions. To investigate whether the $B$. megaterium ATCC13368 whole-cells are capable to hydroxylate DHEA, PREG, dexamethasone, prednisone and digitoxin, $500 \mu \mathrm{l}$ aliquots of fresh over-night cultures were used for small scale conversions. For this purpose, $200 \mu \mathrm{M}$ of each substrate was added to one $500 \mu \mathrm{l}$ aliquot and incubated for 60 minutes at $30^{\circ} \mathrm{C}$ under vigorous shaking. TLC and HPLC analysis revealed that CYP1062-dependent product formation was only detected with PREG and DHEA as substrate (Figure 1). Dexamethasone was not converted in noteworthy amounts by B. megaterium ATCC13368 (Additional file 1: Figure S1). Digitoxigenin and prednisone were converted in the whole-cell system, but in their case product formation was also observed using the CYP106A2deficient knockout strain (Additional file 1: Figures S2 and S3). Because no evident CYP106A2-dependent conversion was detected for dexamethasone, prednisone and digitoxigenin, these substrates were not investigated in more detail in this work. The interference of other $B$. megaterium enzymes or low permeability of the cell membrane for these substrates are possible reasons why their whole-cell conversions were not as promising as those of DHEA and PREG. To circumvent interference with $B$. megaterium enzymes, efficient $E$. coli based wholecell systems are an alternative in this case [23,27].

In contrast to the ring-reduced steroids, DHEA and PREG were converted by B. megaterium ATCC13368 in sufficient amounts to conduct NMR-analysis. According to the TLC analysis, the DHEA conversion resulted in the formation of two products (Figure 1). The main reaction product (Rf 0.43) was identified with NMR-spectroscopy as $7 \beta-\mathrm{OH}-\mathrm{DHEA}$ and the minor reaction product (Rf 0.24) as the $7 \alpha$ stereoisomer (Scheme 2). Whole-cell conversion of PREG with $B$. megaterium ATCC13368 resulted also in the formation of two reaction products ( $\mathrm{Rf} 0.42$ and 0.23 ) (Figure 1). However, in this case only the main product (Rf 0.4) was obtained in sufficient amount and purity for NMR-analysis and was identified as $7 \beta-\mathrm{OH}-\mathrm{PREG}$. Neither DHEA nor PREG reacted with the cyp106a2-knockout strain, why we presume the reaction being strictly CYP106A2 dependent in B. megaterium whole-cells 


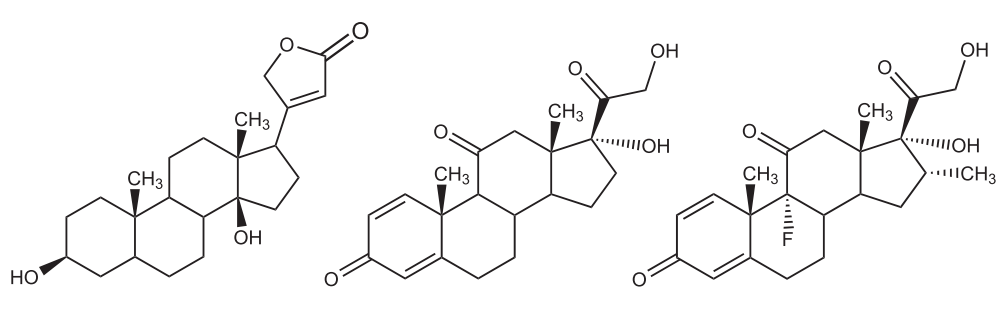

1.

2.

3.<smiles>CC(=O)C1CCC2C3CC=C4C[C@@H](O)CC[C@]4(C)C3CC[C@]12C</smiles>

4.

5.

Scheme 1 Structures of novel CYP106A2 substrates: digitoxigenin (1), prednisone (2), dexamethasone (3), pregnenolone (4), dehydroepiandrosterone (5).

(Figure 1). Because its conversion was most promising, we choose DHEA for further investigations.

\section{CYP106A2-dependent in vitro hydroxylation of DHEA}

The binding of DHEA to CYP106A2 was analyzed in vitro using difference spectroscopy. DHEA did not cause any spectral shift in our assay prompting the assumption that the steroid is not able to remove the axial water from the heme during binding (Figure 2a). Interestingly, the 3-oxo- $\Delta^{4}$ counterpart of DHEA, androstenedione, induced a high-spin shift in our assay (Figure $2 \mathrm{~b}$ ) and could be used to determine the dissociation constant of androstenedione

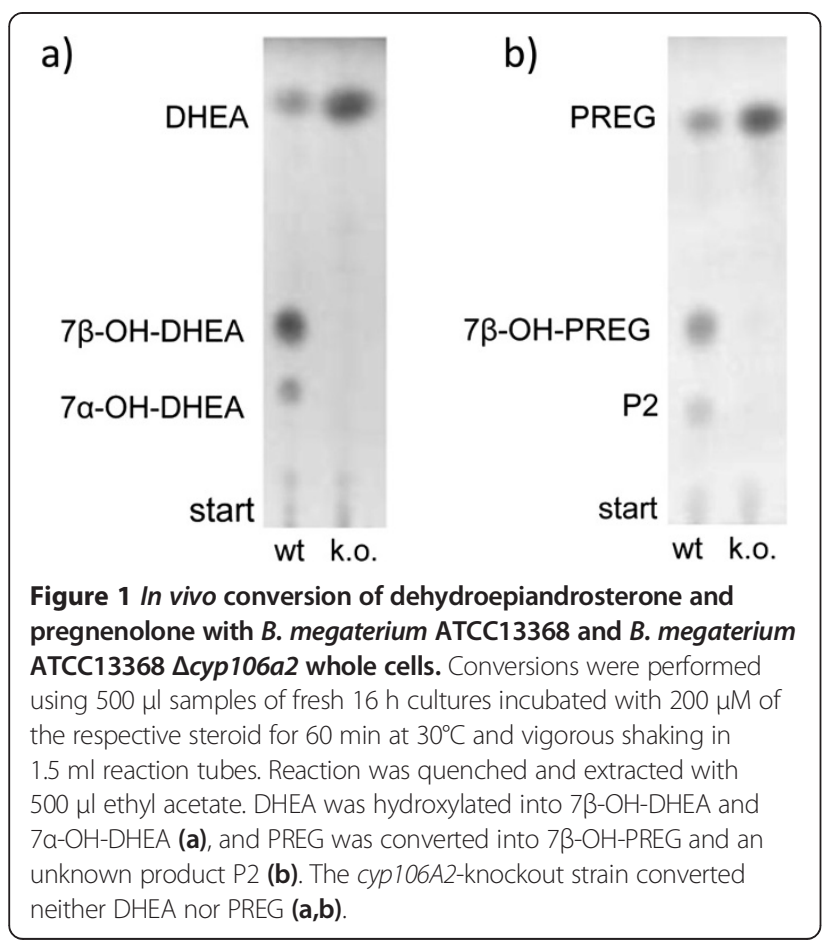

with CYP106A2 to be $92 \pm 11 \mu \mathrm{M}$ (Figure 2c). It is likely that the keto-group at position 3 in the A-ring leads to an alternate binding mode of androstenedione, resulting in a position maybe closer to the heme compared to that of DHEA, eventually leading to the displacement of the axial water ligand.

In a next step, the apparent Michaelis-Menten parameters describing the CYP106A2 dependent DHEA hydroxylation have been estimated. The minor product, $7 \alpha-\mathrm{OH}-\mathrm{DHEA}$, was produced with an apparent reaction velocity $\mathrm{V}_{\text {max }}^{\text {app }}$ of $41 \pm 3.5 \mathrm{nmol}$ product $\min ^{-1} * \mathrm{nmol}$ $\mathrm{P} 450^{-1}$ and an apparent Michaelis constant $\mathrm{K}_{M}^{a p p}$ of $98 \pm$ $22 \mu \mathrm{M}$. The reaction leading to the $\beta$-hydroxylated product is described by a $\mathrm{K}_{M}^{a p p}$ of $168 \mu \mathrm{M}$ with an apparent maximal reaction velocity $\mathrm{V}_{\max }^{a p p}$ of $71 \mathrm{nmol}$ product $\min ^{-1} *$ nmol $\mathrm{P} 450^{-1}$. In comparison, the $15 \beta$-hydroxylation of progesterone is approximately five times faster with a $\mathrm{V}_{\text {max }}^{\text {app }}$ of $337 \mathrm{nmol}$ product $\min ^{-1} \mathrm{nmol} \mathrm{P}_{450}{ }^{-1}$. The conversions of 11-deoxycorticosterone and 11-deoxycortisol are within the same order of magnitude as the $15 \beta$-hydroxylation of progesterone with a $\mathrm{V}_{\max }^{a p p}$ of $246 \mathrm{nmol}$ product $\mathrm{min}^{-1} \mathrm{nmol} \mathrm{P} 450^{-1}$ [28], and $172 \mathrm{nmol}$ product $\min ^{-1} \mathrm{nmol} \mathrm{P450}{ }^{-1}$ [29]. Bleif et al. showed that the conversion of triterpene acids like the abietic acid and the 11-keto- $\beta$-boswellic acid is slower than that of the 3-oxo- $\Delta^{4}$-steroids, with $\mathrm{V}_{\max }^{\text {app }}$ values of 22 and $97 \mathrm{nmol}$ product $\mathrm{min}^{-1}$ nmol $\mathrm{P} 450^{-1}$, respectively $[17,18]$. Thus, the velocity of the CYP106A2-dependent hydroxylation of DHEA is comparable to the hydroxylation of terpene acids with this enzyme.

\section{CYP106A2-dependent in vivo hydroxylation of DHEA Evaluation of DHEA whole-cell conversion}

As mentioned above, cytochrome $\mathrm{P} 450$ in vitro reactions are not suitable for preparative scale production of hydroxysteroids [8]. Therefore, our aim was to establish 


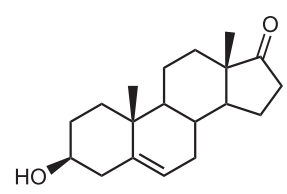

DHEA

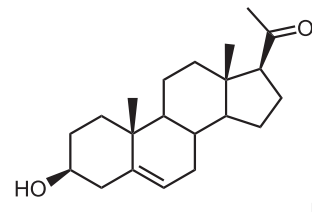

PREG
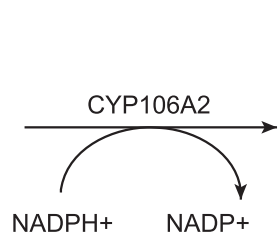

$\mathrm{H}^{+}+\mathrm{O}_{2} \quad \mathrm{H}_{2} \mathrm{O}$

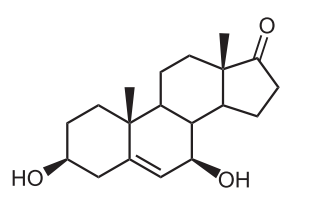

$7 \beta$-OH-DHEA

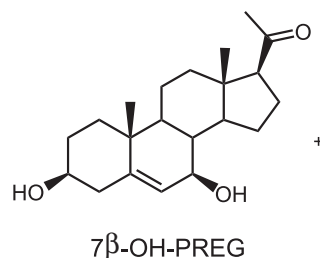

$7 \beta-O H-P R E G$

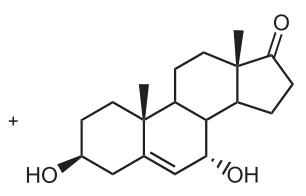

$7 \alpha-O H-D H E A$

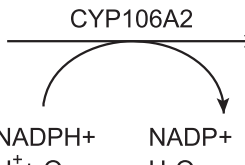

$\mathrm{H}_{2} \mathrm{O}$

Scheme 2 Reaction of dehydroepiandrosterone and pregnenolone with CYP106A2.

an effective whole-cell system for the efficient production of $7 \beta-O H-D H E A$. We used B. megaterium ATCC13368, which expresses CYP106A2 in the stationary phase of growth and has been successfully used for preparativescale production of CYP106A2 reaction products in the past, with higher susceptibility for terpenoic substrates than E.coli $[18,19]$. As described above, the B. megaterium strain ATCC13368 approved to be suitable for in vivo mg scale $7 \beta$-hydroxylation of DHEA. To evaluate the efficiency of DHEA hydroxylation, time-dependent and substrate concentration-dependent bioconversions were performed. Steroids are lipophilic compounds and hence scarcely soluble in water. In order to increase the solubility of DHEA, ethanol was used as co-solvent. However, ethanol is toxic to bacterial cells why its use as solvent is limited in whole-cell biotransformations. It was found that the growth and viability of $B$. megaterium was not influenced by ethanol concentrations up to $5 \%$ (data not shown). Using 5\% ethanol as co-solvent, the solubility of DHEA was increased to $400 \mu \mathrm{M}$. Finally, DHEA concentrations ranging from 50 to $400 \mu \mathrm{M}$ DHEA were added to $50 \mathrm{ml}$ cultures and the reaction was followed until the substrate was consumed (Figure 3). Complete substrate consumption was observed for all tested concentrations. 50, 75 and $100 \mu \mathrm{M}$ DHEA were consumed within one hour (Figure 3). The highest concentration tested, $400 \mu \mathrm{M}$, was completely consumed within three hours. Using $400 \mu \mathrm{M}$, fluctuations in the DHEA conversion between the first three measurement points occurred, which are most probably caused by incomplete mixing of the substrate in the culture and an unbalanced uptake of DHEA into the cells. In order to affirm our finding that $400 \mu \mathrm{M}$ DHEA are consumed completely within 180 minutes the conversion using this concentration was repeated additional three times, in all cases no substrate was detected anymore after 180 minutes, and more than
$99 \%$ of the substrate was consumed within 120 minutes (Figure 4.).

\section{Discontinuous DHEA-feed}

Using ethanol as co-solvent we were able to dissolve $400 \mu \mathrm{M}$ DHEA in B. megaterium ATCC13368 cultures. Using higher DHEA concentrations than $400 \mu \mathrm{M}$, however, aggregation of the substrate was observed. Whereas, solid substrate does not necessarily circumvent product formation, substrate aggregation lowers the conversion rate. To avoid substrate aggregation in the media, a discontinuous feed of DHEA into the reaction was investigated. Because $400 \mu \mathrm{M}$ DHEA are completely converted by B. megaterium ATCC13368 within 180 minutes (Figures 3 and 4), DHEA was fed in $400 \mu \mathrm{M}$ portions to the cells with three hours break between the individual additions. DHEA concentrations in the cultures were measured before and immediately after the substrate additions. The first two feeds after 3 and 6 hours resulted in complete DHEA consumption, meaning a total conversion of $800 \mu \mathrm{M}$ DHEA within 6 hours. After the third feeding step, complete conversion was detected in two of three flasks, resulting in a mean conversion of $98 \pm 2 \%$. The conversion rate dropped further after the addition, within the next 3 hours only $82 \pm 14 \%$ DHEA were hydroxylated. The last $400 \mu \mathrm{M}$ DHEA were not converted into hydroxylated products within the following 12 hours (Figure 5). Altogether, B. megaterium ATCC13368 was able to hydroxylate approximately $1.5 \mathrm{mM}$ DHEA within 12 hours, resulting in a conversion rate of $438.4 \mathrm{mg}^{*} \mathrm{l}^{-1}$ (Figure 5). Although substrate accumulation was avoided, we encountered limitations of the B. megaterium ATCC13368 bioconversion. It can be assumed that the decrease in activity is caused either by direct inhibition of CYP106A2 or indirectly through negative effects of the accumulating products on the B. megaterium ATCC13368 metabolism. 

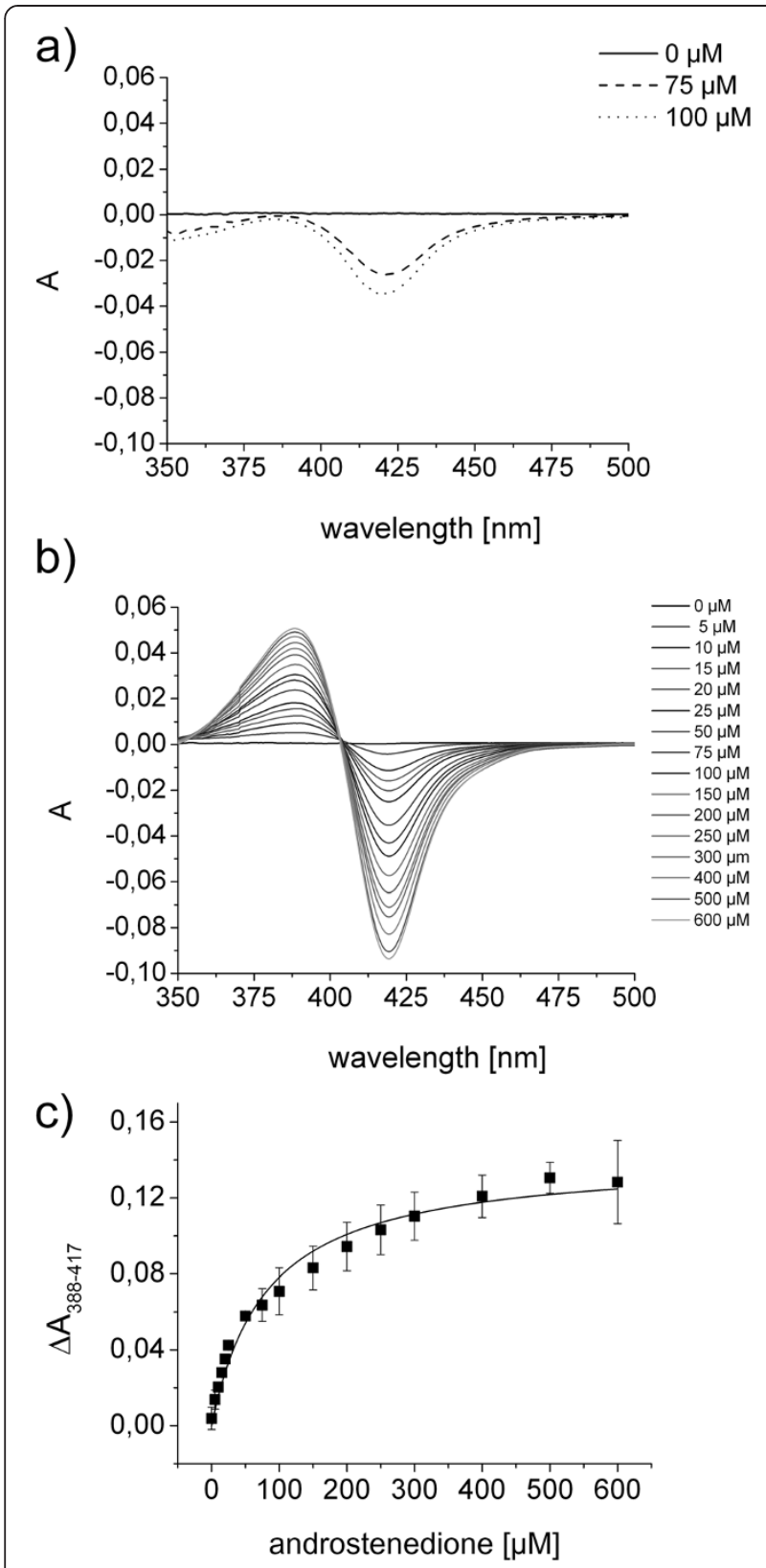

Figure 2 Difference spectroscopy measurements of DHEA and androstenedione binding to CYP106A2. a) Difference spectra of DHEA with CYP106A2 in tandem cuvettes recorded from 350 to $500 \mathrm{~nm} .0$, 75, and $100 \mu \mathrm{M}$ DHEA solved in DMSO were used.

b) Difference spectra of androstenedione recorded from 350 to $500 \mathrm{~nm}$ in tandem cuvettes. Androstenedione was titrated from 0 to $600 \mu \mathrm{M}$ into a $10 \mu \mathrm{M}$ CYP106A2 solution. c) The binding constant $K_{D}$ was calculated by plotting the peak-to-through difference and subsequent hyperbolic fit (solid line). The apparent dissociation constant of androstenedione was calculated to be $K_{D} 92 \pm 11 \mu \mathrm{M}$. The results represent mean values and standard deviations from three independent titrations.

To answer this question, the hydroxylation activity of B. megaterium ATCC13368 cultures was assessed over a time-period of 48 hours. For this purpose, cells were cultivated in broth at $30^{\circ} \mathrm{C}$ and $500 \mu$ l aliquots were sampled after 16, 24, 36, and 48 hours. Conversions were performed with $100 \mu \mathrm{M}$ substrate using $500 \mu \mathrm{l}$ aliquots in $1.5 \mathrm{ml}$ reaction tubes at $30^{\circ} \mathrm{C}$ for 30 minutes. The activity of the cells which were incubated 16 hours prior to the activity assay was defined as $100 \%$ and the activity of the aliquots taken after 24, 36 and 48 hours was calculated relative to this value. No decrease in the hydroxylation efficiency of $B$. megaterium ATCC13368 was observed within 36 hours (Table 2). On the contrary, the mean conversion, relative to the activity measured after 16 hours, increased to $136 \%$, although it has to be taken into account that the standard deviation was quite high. Nevertheless, it can be concluded, that the hydroxylation efficiency of $B$. megaterium ATCC13368 is constant within 36 hours and did not decrease in our experiments until 48 hours. We therefore assume that the limitation observed in the discontinuous feeding reaction is caused by the accumulation of hydroxysteroid in the medium. However, with $438.4 \mathrm{mg}^{*}{ }^{-1}$ DHEA converted within

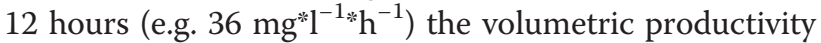
of the systems achieves the minimum process requirements for the industrial production of pharmaceuticals, which is estimated to $1 \mathrm{mg}^{*}{ }^{-1 *} \mathrm{~h}^{-1}$ [30].

\section{Whole-cell conversion using resting cells of Bacillus megaterium}

Although an efficient conversion rate was achieved with $438 \mathrm{mg} \mathrm{l}^{-1}$ by stepwise addition of DHEA to the cultures, the use of whole cells in complex medium hampered the analysis and subsequent chromatography of the reaction products, because of huge amounts of media constituents and B. megaterium metabolites. Resting cells were used to overcome this problem. An additional advantage of resting cells is the avoidance of metabolites which accumulate during bacterial growth and might inhibit the enzyme reaction. E. coli for instance produces indole by metabolizing tryptophan as carbon source if sugar is depleted and this indole in turn can act as cytochrome P450 inhibitor in whole-cell bioconversions [27,31]. However, resting cells are not always better suited for bioconversions than growing cells. For the bioconversion of DHEA with $B$. megaterium resting cells, $50 \mathrm{ml}$ cultures were incubated 16 hours at $30^{\circ} \mathrm{C}$ and $150 \mathrm{rpm}$ in complex medium. Afterwards, cells were centrifuged, washed once and suspended in $50 \mathrm{ml}$ potassium phosphate buffer $(50 \mathrm{mM} \mathrm{pH}$ adjusted to 7.4). $400 \mu \mathrm{M}$ DHEA were added to the reaction mixture and the conversion was followed using rpHPLC analysis. As shown in Figure 6, using resting cells, $400 \mu \mathrm{M}$ DHEA were completely converted within 60 minutes, whereas it took 180 minutes to completely convert the same amount using growing cells (Figures 3 and 4). Taken together, our experiments demonstrate that the conversion rate was considerably increased using $B$. megaterium resting cells compared with growing cells. 

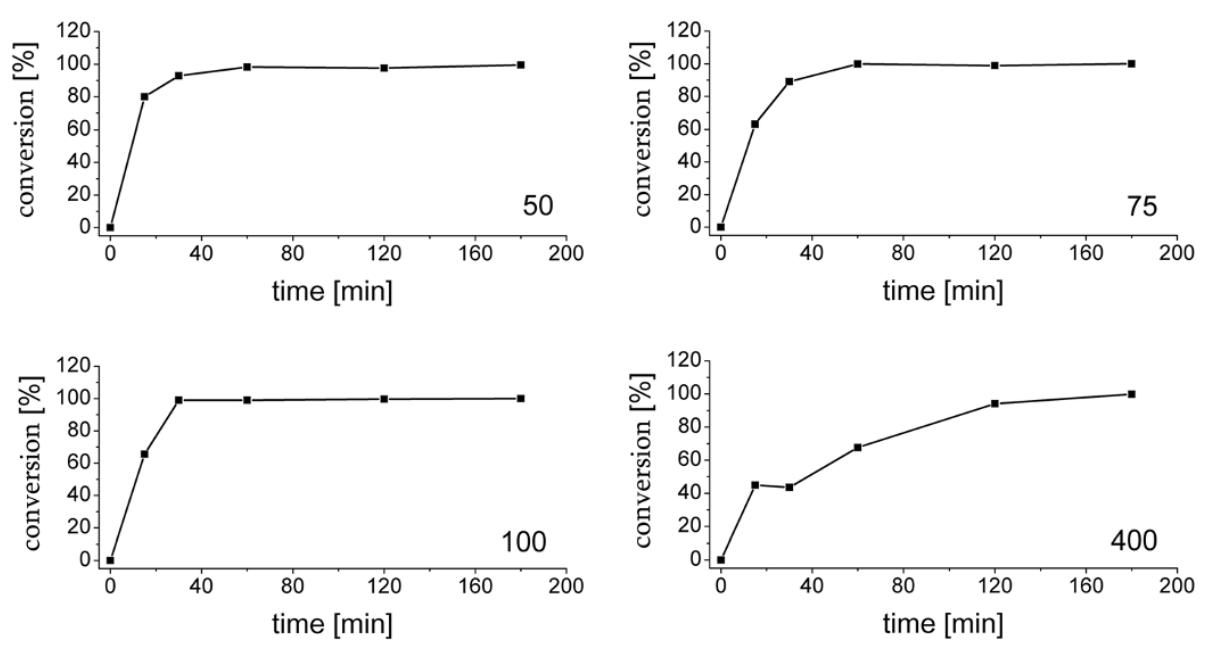

Figure 3 Time- and concentration- dependent DHEA conversions using B. megaterium ATCC13368 whole-cell bioconversion. $50 \mathrm{ml} B$. megaterium WT cultures were incubated at $30^{\circ} \mathrm{C}$ and $150 \mathrm{rpm}$ for 16 hours prior to substrate addition. 50, 75, 100 and $400 \mu \mathrm{M}$ DHEA (max. 5\% ethanol $\mathrm{v} / \mathrm{v}$ ) were added into the cultures and reactions were followed using TLC analysis. Samples were taken at indicated time points, (500 $\mu$ l) quenched, and extracted with $500 \mu$ lethyl acetate. The organic phase was separated, evaporated to dryness, and chromatographed using ethyl acetate as mobile phase on TLC-plates. After anisaldehyde staining the relative substrate consumption in \% was calculated using the spot intensity with the Image-Lab'M (BIO-RAD, Germany) software.

\section{Conversion of DHEA using the recombinant B. megaterium MS941_pSMF2.1CAA strain}

B. megaterium ATCC13368 expresses CYP106A2 in the stationary phase of growth. The maximum P450 content in our experiments was reached after 24 hours with

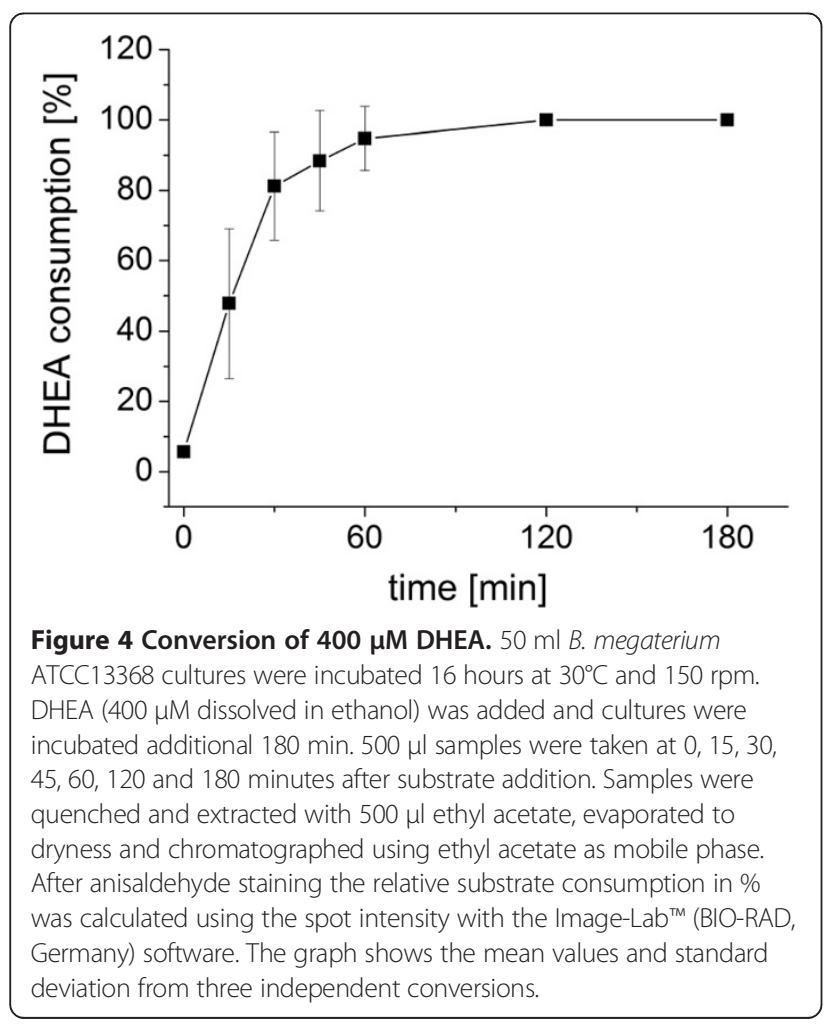

$135 \mathrm{nmol}^{* \mathrm{l}^{-1}}$ culture (Figure 6). No P450 was detected in the respective knock-out strain (Figure 6). For biotechnological purposes, it would be of interest to increase the expression rate of CYP106A2 and its redox partners. However, no inducer of CYP106A2 expression in B. megaterium is known so far. In our experiments, DHEA was also not able to induce CYP106A2 expression in B. megaterium. In order to increase the CYP106A2 amount in B. megaterium, an expression system for CYP106A2 together with its heterologous redox partners AdR and $\mathrm{Adx}_{4-108}$ in the strain B. megaterium MS941 has been developed in our laboratory [18]. Using this system, the expression rate of $\mathrm{P} 450$ averages $450 \mathrm{nmol}^{*} \mathrm{l}^{-1}$ culture, displaying a three-fold increase compared to the wild type strain (Figure 7). Although B. megaterium MS941 contains four P450s in its genome [32], Western Blot analysis conducted by Bleif et al. showed that the P450 content in the expression system is mainly composed of CYP106A2. Using this overexpression strain, the conversion rate of 11 -keto- $\beta$-boswellic acid was increased by the factor of four compared with the wild type [18]. Therefore, we aimed to improve the DHEA conversion using the recombinant expression strain B. megaterium MS941 overexpressing CYP106A2. According to the results achieved with the ATCC13368 strain (shown in Figure 6), resting cells were used for the bioconversion. Again, $400 \mu \mathrm{M}$ DHEA was added and samples were taken after $0,1,4,8$ and 24 hours. To corroborate the CYP106A2 dependence of DHEA conversion, the MS941 strain without the expression vector was used as control. The control strain did not convert DHEA within $24 \mathrm{~h}$ of incubation (Additional 


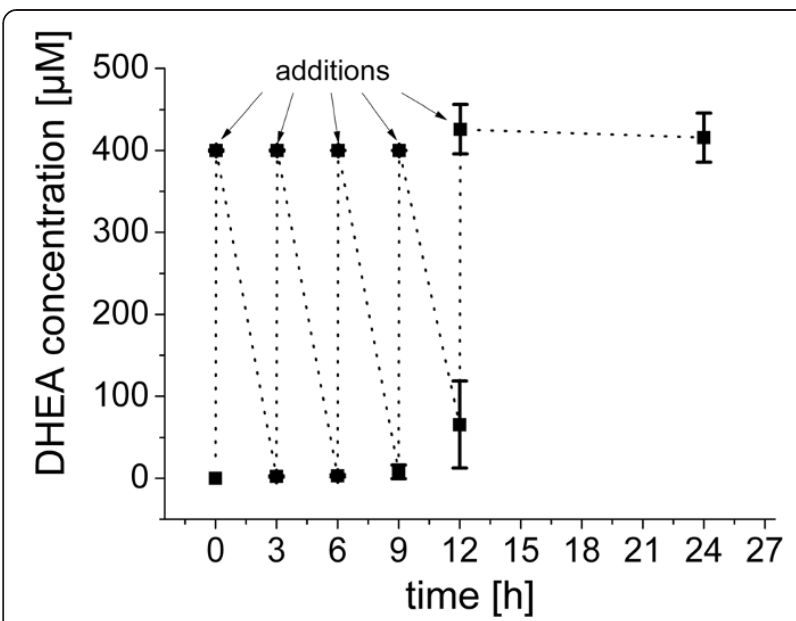

Figure 5 Discontinuous feed of DHEA to $B$. megaterium ATCC13368. B. megaterium ATCC13368 cultures were incubated at $30^{\circ} \mathrm{C}$ and $150 \mathrm{rpm}$ in broth. After $16 \mathrm{~h}$ cultivation $400 \mu \mathrm{M}$ DHEA was added $(0 \mathrm{~h}) 5$ times with 3 hours break between the individual additions. After the last addition (reaching $2000 \mu \mathrm{M}$ DHEA in total) the cultures were incubated for additional $12 \mathrm{~h}$. DHEA concentration in the cultures was calculated using TLC analysis and the software ImageLab ${ }^{T M}$ (BIO-RAD, Germany).

file 1: Figure S4). To our surprise, the conversion rate of B. megaterium MS941_pSMF2.1CAA cells was comparable to that of resting cells of the ATCC13368 strain, $400 \mu \mathrm{M}$ DHEA were completely converted after $60 \mathrm{mi}-$ nutes (Figure 6). Obviously, there are other rate-limiting parameters in CYP106A2-dependent DHEA conversion in $B$. megaterium, most probably substrate uptake and product exit, which are known bottlenecks of whole-cell conversions. Interestingly, the product pattern differed in the reactions performed with the ATCC13368 strain from that using the recombinant expression system. The latter shifted the selectivity in favor of the reaction leading to the $\beta$-hydroxylated product. The ATCC13368 strain converted DHEA into $70 \% 7 \beta-\mathrm{OH}-\mathrm{DHEA}$ and $30 \% 7 \alpha-\mathrm{OH}-\mathrm{DHEA}$, whereas the MS941_pSMF2.1CAA strain produced 90\% $7 \beta-\mathrm{OH}-\mathrm{DHEA}$ (Figure 6, Additional file 1: Figure S4). Although no increase in the conversion rate could be measured with the overexpression strain, due to the increased

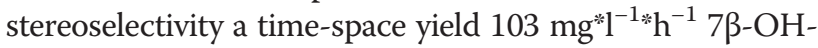
DHEA was calculated using this system, reflecting the

Table 2 Hydroxylation activity of B. megaterium ATCC13368 monitored over a period of 48 hours

\begin{tabular}{cccc}
\hline $\mathbf{1 6} \mathbf{h}$ & $\mathbf{2 4} \mathbf{h}$ & $\mathbf{3 6} \mathbf{h}$ & $\mathbf{4 8} \mathbf{h}$ \\
\hline $100 \%$ & $105 \pm 3 \%$ & $136 \pm 42 \%$ & $84 \pm 22 \%$ \\
\hline
\end{tabular}

Cells were cultivated in $50 \mathrm{ml}$ Erlenmeyer flasks at $30^{\circ} \mathrm{C}$ and $150 \mathrm{rpm} .500 \mu \mathrm{l}$ samples were taken at time points indicated. Conversions were performed with $100 \mu \mathrm{M}$ substrate in $1.5 \mathrm{ml}$ reaction tubes at $30^{\circ} \mathrm{C}$ for $60 \mathrm{~min}$. The reactions were quenched and extracted with ethyl acetate and the steroid conversion was analyzed with HPLC. The activity of $B$. megaterium after $16 \mathrm{~h}$ cultivation was defined as $100 \%$. Results are shown as mean values and deviations are from two independent experiments. fastest CYP106A2-dependent hydroxysteroid production described using B. megaterium whole-cells up to now.

At this point it cannot be fully explained why the use of the recombinant expression system alters the selectivity of the reaction. However, similar observations have been made with the $E$. coli system for the production of hydroxylated progesterone derivatives using CYP106A2 mutants, were the in vitro selectivity differed from that observed in the in vivo conversions [33].

\section{Conclusions}

Summarizing the results, we broadened the substrate spectrum of CYP106A2 and identified novel reaction products. Screening of a focused steroid library revealed, for the first time, that CYP106A2 converts 3-hydroxy- $\Delta^{5}$ and A-ring reduced steroids. The major group of CYP106A2 substrates still consists of 3-oxo- $\Delta^{4}$ steroids, but the present work describes for the first time its ability to hydroxylate pregnenolone (PREG) and dehydroepiandrosterone (DHEA), both mainly at position $7 \beta$. Assuming that both ends of the steroid molecule interact with amino acid side chains to position the steroid above the heme, four principal binding modes have been described in the literature; normal, reverse, normal inverted and reverse inverted [34]. The differences in the hydroxylation position of 3-oxo or 3-hydroxy steroids most probably result from alternative binding modes in the active side of CYP106A2, assessing, for instance, the differences between DHEA and androstenedione hydroxylation: The change of the hydrogenbond-acceptor $(=\mathrm{O})$ into a donor $(-\mathrm{OH})$, at position $\mathrm{C}-3$, may cause an inverted or reversed binding of the molecule. Another possible explanation is that the loss of one hydrogen-bond acceptor loosens the binding at $\mathrm{C}-3$, so that the steroid slips perhaps deeper into the reactive pocked resulting in that the $\mathrm{C}-15$ is moved from and the $\mathrm{C}-7$ towards the heme-iron.

Even though the mechanistic insights of CYP106A2 steroid hydroxylation remain elusive, its production of human DHEA metabolites is highly interesting, because 7-oxygenated DHEA derivatives have been discussed as neuroprotective, immune-modulatory and anti-inflammatory agents [35]. Besides, hydroxylated steroids are highly interesting lead compounds for drug development targeting P450 enzymes, especially CYP19A1 (aromatase) which is involved in the formation of post-menopausal breast cancer. Li et al., for instance, showed that 7-substituted 1,4,6-androstatriene-3,17-diones can act as enzyme-activated irreversible aromatase inhibitors [36]. The bioconversion rates of the systems described achieve appreciable rates, up to $400 \mu \mathrm{M}$ DHEA within one hour, thus comparable to described fungal systems [37]. To our opinion the major challenge for further optimizations of DHEA bioconversion with $B$. megaterium is the limitation most probably caused by accumulation of hydroxysteroids in the reaction 

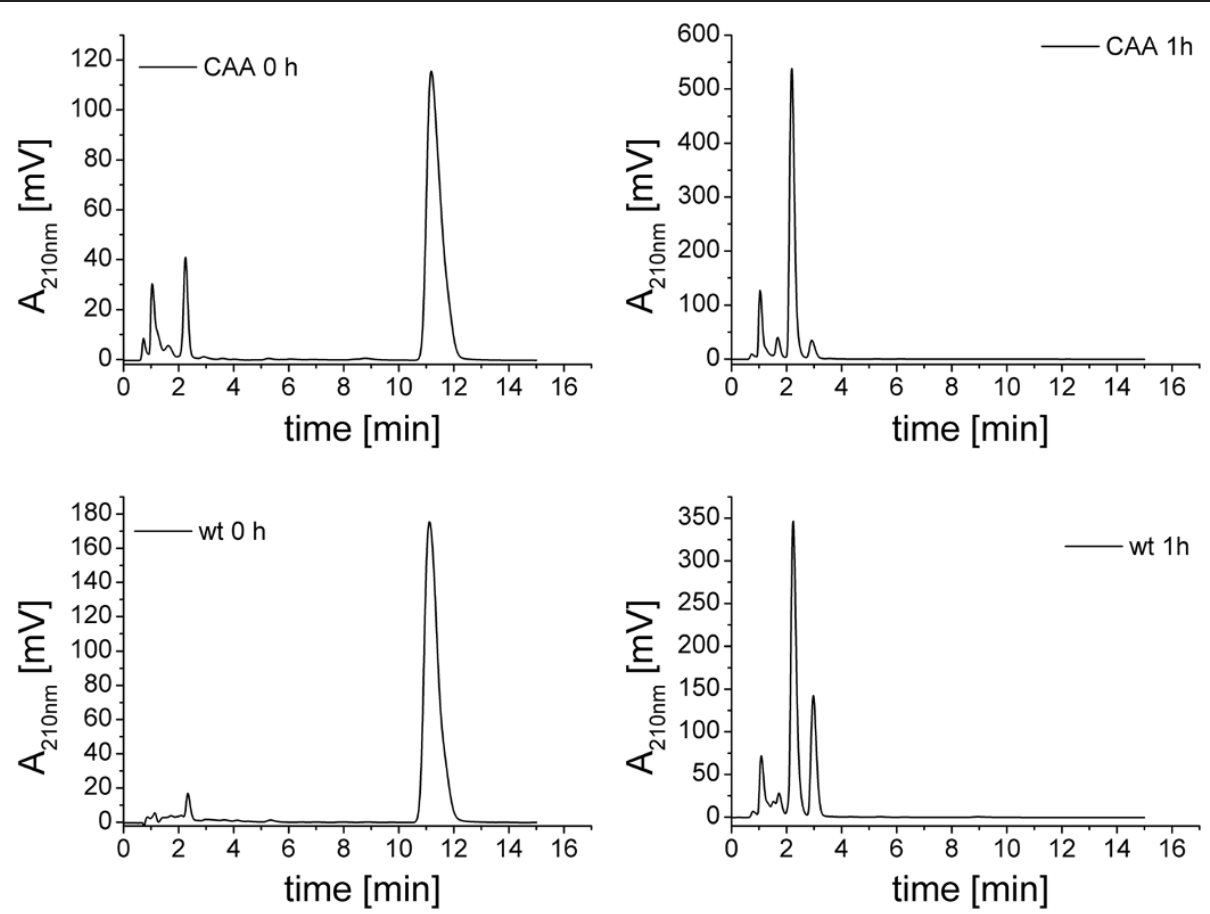

Figure 6 HPLC chromatograms of DHEA conversion using resting cells B. megaterium ATCC13368 (wt) and MS941_pSMF2.1CAA (CAA). Cultures were incubated at $30^{\circ} \mathrm{C}$ and $150 \mathrm{rpm}$ for $24 \mathrm{~h}$, washed once and suspended in $50 \mathrm{ml}$ potassium phosphate buffer adjusted to pH 7.4 . Heterologous protein expression in B. megaterium MS941_pSMF2.1CAA cells was induced with 0.5\% (w/v) xylose. DHEA (400 mM) was added as ethanolic solution ( $5 \% \mathrm{v} / \mathrm{v}$ ). Samples were taken directly after substrate addition (CAA 0 h, wt 0 h) and after $1 \mathrm{~h}$ (CAA 1 h, wt 1 h). No DHEA $\left(R_{T}=11.5 \mathrm{~min}\right)$ was detected in the $1 \mathrm{~h}$ samples.

mixture. This can be met by performing the conversions in liquid-liquid biphasic-systems, in which a water-immiscible liquid phase is used as substrate reservoir and product recipient. Such systems have already been successfully conducted with recombinant $E$. coli and solvent tolerant Pseudomonas putida strains $[38,39]$. Yet, combined with the recombinant expression strain, which produced the $7 \beta$-stereoisomer with $90 \%$ de resulting in a space-time

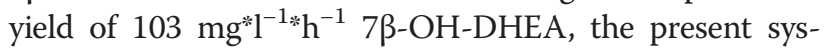
tems provides an excellent starting point to establish biotechnological processes for the production of high-value hydroxysteroids.

\section{Material and methods}

\section{Chemicals and solvents}

All chemicals used in this work were from standard sources and of highest purity available. Solvents used for chromatography were of gradient grade, solvents used for large scale extraction were of analytical purity. The focused steroid library used in this work consisted of: dehydroepiandrosterone (DHEA), pregnenolone (PREG), estradiol, estrone, dexamethasone, prednisone, androstenedione, stigmasterol, cholesterol and cis-, trans-androsterone. All steroids were obtained from Sigma-Aldrich (Sigma-Aldrich Biochemie GmbH, Germany) and were of highest purity available.

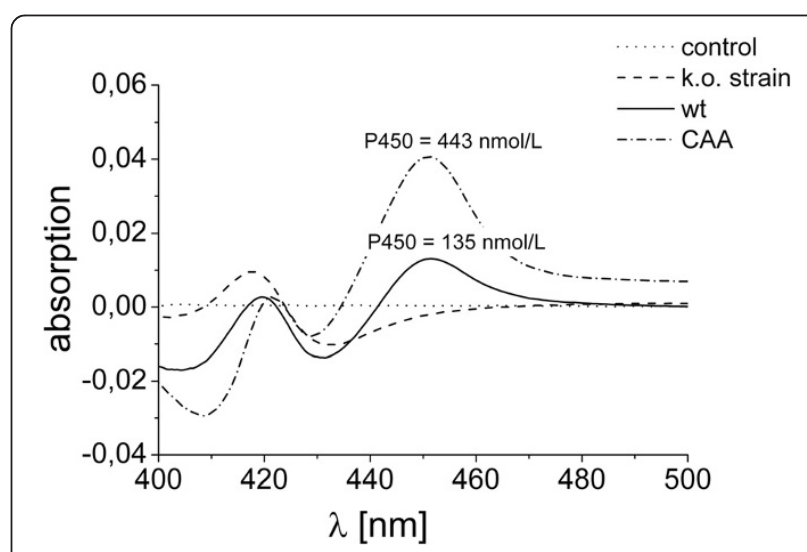

Figure 7 P450 content in the used B. megaterium strains. CO-difference spectra recorded after 24 hours cultivation of $B$. megaterium ATCC13368 (wt), cypro6a2-knockout strain (k.o. strain), and MS941_pSMF2. 1CAA (CAA) in crude lysates. Cells were incubated at $30^{\circ} \mathrm{C}$ and $150 \mathrm{rpm}$ in broth, which was supplemented with $35 \mu \mathrm{g} / \mathrm{ml}$ tetracycline for the cultivation of B. megaterium ATCC13368 cyp106a2-knockout and B. megaterium MS941 cells. The protein expression in MS941_pSMF2.1CAA cells was induced by adding $0.25 \%$ xylose to the culture at $\mathrm{OD}_{600}$ of 0.4 and subsequent incubation for 24 hours. 


\section{Bacillus megaterium: strains plasmids and cultivation} Bacillus megaterium ATCC13368, the host strain of CYP106A2, as well as a respective knockout strain Bacillus megaterium ATCC13368 $\Delta c y p 106 A 2$, were both kind gifts of Dr. R. Rauschenbach (Schering AG, Berlin, Germany). Bacillus megaterium MS941 was kindly provided by Prof. Dieter Jahn (Institute of Microbiology, TU Braunschweig, Germany). Besides, we used a xylose-inducible recombinant expression system, which has recently been established in our group, to co-express CYP106A2 and its heterologous redox-partners adrenoxodin (Adx) and adrenodoxin reductase (AdR) using the expression vector pSMF2.1_CAA in B. megaterium MS941 [18].

Unless otherwise noted, Bacillus megaterium cells were cultivated in complex medium consisting of $25 \mathrm{~g}$ yeast extract (Becton, Dickinson and Company, USA), $12 \mathrm{~g}$ soytone (Becton, Dickinson and Company, USA) and $5 \mathrm{ml}$ glycerol buffered with potassium phosphate buffer (2.31 g $\mathrm{KH}_{2} \mathrm{PO}_{4}, 12.5 \mathrm{~g} \mathrm{~K}_{2} \mathrm{HPO}_{4}$ ) adjusted to $\mathrm{pH} 7.4$ in $1 \mathrm{l}$ distilled water. Cultivations were generally conducted at $30^{\circ} \mathrm{C}$ and $150 \mathrm{rpm}$ in baffled shake-flasks (300 $\mathrm{ml}$ or $2 \mathrm{l}$ ). For the cultivation of MS941 cells transformed with the plasmid pSMF2.1_CAA and for the cultivation of the ATCC13368 $\Delta c y p 106 a 2$-strain the medium was supplemented with $10 \mathrm{mg}^{* 1}{ }^{-1}$ tetracycline.

\section{Protein expression and purification}

CYP106A2, a truncated form of bovine adrenodoxin $\left(\mathrm{Adx}_{4-108}\right)$ and bovine adrenodoxin reductase (AdR) were expressed and purified as described elsewhere $[19,40,41]$.

\section{In vitro conversion and catalytic activity}

Substrate conversions with CYP106A2 were conducted using an in vitro reconstituted system with bovine $\mathrm{Adx}_{4-108}$ $(5 \mu \mathrm{M})$ and bovine $\operatorname{AdR}(0.5 \mu \mathrm{M})$ as redox partners for CYP106A2 $(0.25 \mu \mathrm{M})$. An NADPH regeneration system consisting of glucose-6-phosphate-dehydrogenase (1 U), glucose-6-phosphate $(5 \mathrm{mM})$ and $\mathrm{MgCl}_{2}(1 \mathrm{mM})$ was used for the continuous supply with electrons. Reactions were carried out in $1.5 \mathrm{ml}$ reaction tubes at $30^{\circ} \mathrm{C}$ and $750 \mathrm{rpm}$ in $50 \mathrm{mM}$ HEPES-buffer adjusted to $\mathrm{pH} 7.4$ and supplemented with $0.05 \%(\mathrm{v} / \mathrm{v})$ Tween 20 . The total reaction volume was $250 \mu$ l. Reactions were started by adding $500 \mu \mathrm{M}$ pre-warmed $\left(30^{\circ} \mathrm{C}\right) \mathrm{NADPH}$ dissolved in $50 \mathrm{mM}$ HEPES-buffer. For the endpoint-kinetics the reactions were incubated for two minutes. The reaction times were ten minutes in order to screen the steroid library for novel CYP106A2 substrates. Reactions were stopped and extracted twice with $500 \mu$ l ethyl acetate. The organic phases were pooled, evaporated to dryness and subsequently chromatographed via reversed-phase high-performance-liquid-chromatography (rpHPLC).

\section{Spectroscopic binding assay}

Difference spectroscopy was used to investigate the binding behavior of DHEA and androstenedione to CYP106A2. For this purpose, tandem cuvettes were used as described in the literature $[42,43]$. In one chamber of each cuvette $10 \mu \mathrm{M}$ enzyme in $50 \mathrm{mM}$ potassium phosphate buffer ( $\mathrm{pH}$ 7.4) was added, whereas buffer without enzyme was filled into the other chamber. After performing the baseline correction, steroids were titrated into the enzyme solution of the measurement cuvette and into the chamber containing only buffer of the reference cuvette. The solvent DMSO alone was titrated vice versa to avoid falsification of the measurement according to imbalanced dilution of the enzyme solution. After baseline correction, the difference spectra were recorded from 300 to $500 \mathrm{~nm}$. For the steroids $5 \mathrm{mM}, 10 \mathrm{mM}$ and $40 \mathrm{mM}$ stock solutions were prepared using DMSO as solvent. Titrations were performed using a maximal concentration of $2 \%$ DMSO $(\mathrm{v} / \mathrm{v})$ and final steroid concentrations ranging from $0-600 \mu \mathrm{M}$. The $K_{\mathrm{D}}$ value was calculated by plotting the peak-to-through differences $\Delta \mathrm{A}(380 \mathrm{~nm}-417 \mathrm{~nm})$ against the total ligand concentration. The apparent equilibrium dissociation constant was calculated by hyperbolic regression of the resulting plot $\left(\mathrm{y}=\left(\mathrm{P}_{1} \mathrm{x} / \mathrm{P}_{2}+\mathrm{x}\right)\right.$ with $\mathrm{P}_{2}=\mathrm{K}_{\mathrm{D}}$ ) using the origin software version 8.6 (OriginLab Corporation, Massachusetts, USA).

\section{Whole-cell biotransformations}

Whole cell bioconversions were performed with $B$. megaterium ATCC 13368 and B. megaterium MS941_pSMF2. $1 C A A$ cultures. As control a $\Delta c y p 106 a 2$ knock-out strain of B. megaterium ATCC 13368 [44] and the MS941 strain without the expression plasmid for CYP106A2 were used. In each case pre-cultures were prepared by inoculating $50 \mathrm{ml}$ broth $(25 \mathrm{~g}$ yeast extract, $12 \mathrm{~g}$ soytone, $5 \mathrm{ml}$ glycerine and no further additives) with $50 \mu \mathrm{l}$ of deep-frozen stocks and incubated 24 hours at $30^{\circ} \mathrm{C}$ and $150 \mathrm{rpm}$ in baffled flasks. Main cultures were inoculated by diluting an aliquot of the pre-cultures 1 to 100 with fresh medium. For the incubation of B. megaterium ATCC 13368 cells the cultures were incubated $16 \mathrm{~h}$ depicting the stationary phase of growth, to ensure the expression of CYP106A2. To express CYP106A2 with B. megaterium MS941 strain transformed with the expression plasmid pSMF2.1_CAA, $0.25 \%(\mathrm{w} / \mathrm{v})$ xylose were added for induction when the main culture reached $\mathrm{OD}_{600}$ of 0.4 . Protein expression was conducted for 24 hours after induction as described [18]. The $16 \mathrm{~h}$ cultures of the ATCC13368 and the $24 \mathrm{~h}$ cultures of the MS941_pSMF2.1CAA strain, consistent with an OD of 20 and approximately $40 \mathrm{~g}$-wcw per liter were used for whole-cell conversions. Substrates were generally added as ethanolic solutions, with the final ethanol concentration not exceeding $5 \%(\mathrm{v} / \mathrm{v})$. Unless otherwise stated, conversions were performed with $50 \mathrm{ml}$ cultures in 
$300 \mathrm{ml}$ baffled shake flasks at $30^{\circ} \mathrm{C}$ and $150 \mathrm{rpm}$ using the soytone containing broth or $50 \mathrm{mM}$ potassium phosphate buffer (resting cell conversions). Samples were taken at indicated time points; reactions were quenched and concomitantly extracted with $500 \mu \mathrm{l}$ ethyl acetate. To follow the CYP106A2 catalyzed reactions, the organic phases were collected, evaporated to dryness, and analyzed via HPLC or TLC.

For the preparative scale conversions of dehydroepiandrosterone (DHEA) and pregnenolone (PREG), $1 \mathrm{~L}$ cultures, distributed to five $2 \mathrm{~L}$ baffled shake flasks $(200 \mathrm{ml}$ each), were inoculated with $1 \mathrm{ml}$ of a deep-frozen stock $(200 \mu \mathrm{l} \mathrm{each})$ and cultivated for $16 \mathrm{~h}$ at $30^{\circ} \mathrm{C}$ and $150 \mathrm{rpm}$. $115 \mathrm{mg}$ of DHEA and $120 \mathrm{mg}$ of PREG, respectively, were dissolved in $50 \mathrm{ml}$ ethanol and added to the cultures after $16 \mathrm{~h}$ incubation. Samples were taken every two hours and reactions were monitored using TLC analysis. When the substrate was completely consumed, the cultures were pooled and extracted three times with $500 \mathrm{ml}$ ethyl acetate. The organic phases were combined, dried and the resulting residue was chromatographed via a silica gel (60) column, using ethyl acetate as mobile phase. $10 \mathrm{ml}$ fractions were collected and analyzed via TLC; homogenous fractions containing the reaction products were pooled and evaporated to dryness. Because of a yellowish impurity, the main product of the DHEA reaction was additionally chromatographed via a silica gel column using a mixture of hexane/ethyl acetate/methanol in a ratio of 1:4:0.5 as mobile phase. The resulting homogeneous fractions were evaporated to dryness and analyzed by TLC. Those products which were obtained in sufficient amounts and purity were analyzed by NMR spectroscopy. The yields after silica gel chromatography were $46 \mathrm{mg}$ for the first DHEA reaction product (chromatographed twice), $23 \mathrm{mg}$ for the second reaction product and $42 \mathrm{mg}$ for the main pregnenolone product and approximately $1 \mathrm{mg}$ for the second pregnenolone product.

\section{Chromatographic methods}

TLC was used to monitor the in vivo biotransformation using growing cells in complex medium and for the analysis of homogenous fractions obtained after silica gel column chromatography. Samples were spotted onto TLC aluminum plates (4 x $8 \mathrm{~cm}$; silica 60; layer thickness, $0.2 \mathrm{~mm}$; Roth, Karlsruhe, Germany), and developed once in a rectangular solvent tank containing ethyl acetate as mobile phase. Spots were detected using an anisaldehyde dipping bath (4-methoxybenzaldehyde, $5 \mathrm{ml}$; sulfuric acid, $2.5 \mathrm{ml}$; glacial acetic acid, $3.75 \mathrm{ml}$; ethanol, $278.75 \mathrm{ml}$ ), the reaction of anisaldehyde-sulfur reagent with the steroids and terpenoids to colored products was started by heating the plates to $100^{\circ} \mathrm{C}$ using a hot air gun.

Reversed-phase high-performance-liquid-chromatography (HPLC) was performed using a Jasco system (Pu-980
HPLC pump, an AS-950 sampler, and UV-975 UV/visible detector, and a LG-980-02 gradient unit from Jasco, GrossUmstadt, Germany). A reversed phase ec MN Nucleodor C18 (5 $\mu \mathrm{m}, 4.0 \times 125 \mathrm{~mm})$ column (Macherey-Nagel, Bethlehem, PA, USA) was used. A mixture of acetonitrile and water (40:60) served as mobile phase. Steroids containing a keto-en moiety were detected at $254 \mathrm{~nm}$. From the set of steroids without keto-en-moiety only DHEA was monitored with rpHPLC at $210 \mathrm{~nm}$, but only after conversion in vitro or with resting cells, because the samples from whole-cell conversions in complex-media included to many impurities, hampering the rpHPLC analysis at $210 \mathrm{~nm}$. In all measurements the column oven temperature was kept at $40^{\circ} \mathrm{C}$ and the flow rate of the mobile phase was $1 \mathrm{ml}^{*} \mathrm{~min}^{-1}$.

\section{NMR spectroscopy}

NMR spectra were recorded in $\mathrm{CDCl}_{3}$ at $300 \mathrm{~K}$ with a Bruker DRX 500 NMR spectrometer. The chemical shifts were given relative to $\mathrm{CDCl}_{3}$ at $\delta 77.00\left({ }^{13} \mathrm{C} \mathrm{NMR}\right)$ or $\mathrm{CHCl}_{3}$ at $\delta$ 7.24 ( $\left.{ }^{1} \mathrm{H} \mathrm{NMR}\right)$ using the standard $\delta$ notation in parts per million (ppm). The 2D NMR spectra were recorded as gs-HHCOSY, gs-NOESY, gs-HSQCED and gs-HMBC.

The conversion of DHEA led to the production of the known $7 \alpha-\mathrm{OH}$ - and $7 \beta-\mathrm{OH}-\mathrm{DHEA}$ epimers. Their structures followed directly from the comparison of their NMR data with those from literature [45].

\section{3ß,7a-Dihydroxyandrost-5-en-17-one (7a-OH-DHEA)}

${ }^{1} \mathrm{H} \mathrm{NMR}\left(\mathrm{CDCl}_{3}, 500 \mathrm{MHz}\right): \delta 0.86 s(3 \mathrm{H}, 3 \mathrm{x} \mathrm{H}-18), 0.99 s$ $(3 \mathrm{H}, 3 \mathrm{x} \mathrm{H}-19), 1.09 m$ (H-1a), $1.25 m$ (H-12a), $1.26 m$ (H-9), $1.48 m$ (H-11a), $1.49 m$ (H-2a), $1.55 m$ (H-15a), $1.64 m$ (H-8), $1.68 m$ (H-11b), $1.77 m$ (H-14), $1.80 \mathrm{~m}$ (H-12b), $1.83 m$ (H-2b), $1.85 m$ (H-1b) $2.08 \mathrm{~m}$ (H-15b), $2.12 \mathrm{~m}$ (H-16a), $2.27 \mathrm{~m}$ (H-4a), $2.34 \mathrm{~m}$ (H-4b), $2.45 \mathrm{~m}$ (H-16b), $3.54 \mathrm{~m}(\mathrm{H}-3), 3.94 d d(J=5.0$ and $5.0 \mathrm{~Hz}, \mathrm{H}-7)$, $5.61 d d(5.0$ and $2.0 \mathrm{~Hz}, \mathrm{H}-6) .{ }^{13} \mathrm{C} \mathrm{NMR}\left(\mathrm{CDCl}_{3}\right.$, $125 \mathrm{MHz}): \delta 13.29$ (C-18), 18.28 (C-19), 20.09 (C-11), 21.93 (C-15), 31.07 (C-12), 31.30 (C-2), 35.80 (C-16), 36.97 (C-1), 37.22 (C-10), 37.53 (C-8), 41.95 (C-4), 42.62 (C-9), 44.96 (C-14), 47.11 (C-13), 64.28 (C-7), 71.17 (C-3), 123.57 (C-6), 146.57 (C-5), 221.10 (C-17).

\section{$3 \beta, 7 \beta$-Dihydroxyandrost-5-en-17-one (7 $\beta$-OH-DHEA)}

${ }^{1} \mathrm{H} \mathrm{NMR}\left(\mathrm{CDCl}_{3}, 500 \mathrm{MHz}\right): \delta 0.88 s(3 \mathrm{H}, 3 \mathrm{x} \mathrm{H}-18)$, $1.05 m$ (H-1a), $1.06 s$ (3H, 3x-H19), $1.08 m$ (H-9), $1.23 m$ (H-12a), $1.42 \mathrm{~m}$ (H-14), 1.48 m (H-11a), $1.50 m$ (H-2a), $1.55 m$ (H-8), $1.68 m$ (H-11b), $1.82 m$ (H-12b), $1.83 m$ (H-15a), $1.84 m$ (H-1b), $1.85 m$ (H-2b), $2.09 m$ (H-16a), $2.22 m$ (H-15b), 2.24m (H-4a), $2.33 d d d(\mathrm{~J}=13.5,5.0$ and $2.0 \mathrm{~Hz}, \mathrm{H}-4 \mathrm{~b}), 2.45 m(\mathrm{H}-16 \mathrm{~b}), 3.53 m(\mathrm{H}-3), 3.93$ $d d d(J=8.0,2.0$ and $2.0 \mathrm{~Hz}, \mathrm{H}-7), 5.29 d d(J=2.0$ and $2.0 \mathrm{~Hz}, \mathrm{H}-6) .{ }^{13} \mathrm{C} \mathrm{NMR}(\mathrm{CDCl} 3,125 \mathrm{MHz}): \delta 13.60$ 
(C-18), 19.19 (C-19), 24.21 (C-15), 20.41 (C-11), 31.51 (C-12), 31.51 (C-2), 35.98 (C-16), 36.69 (C-10), 36.90 (C-1), 40.52 (C-8), 41.67 (C-4), 47.78 (C-13), 48.27 (C-9), 51.23 (C-14), 71.27(C-3), 72.88 (C-7), 125.50 (C-6), 143.75 (C-5), 221.11 (C-17).

In contrast to pregnenolone the NMR spectra of its conversion product gave hint to an additional hydroxyl group $(\delta 73.14(\mathrm{CH})$ and $\delta 3.83)$. Its position at $\mathrm{C}-7$ was deduced from $\mathrm{HMBC}$ correlations between $\mathrm{H}-7$ and the carbons C-5 $(\delta 143.49(\mathrm{C})$ and C-6 $(\delta 125.49(\mathrm{CH}))$ of the double bond and the vicinal coupling of $\mathrm{H}-7$ with $\mathrm{H}-6(\delta 5.27)$ in the HHCOSY. The NOESY spectrum revealed correlations between $\mathrm{H}-7$ and the axial H-9 $(\delta$ 1.07) and H-14 $(\delta 1.27)$ indicating that all these protons are in axial position and logically consistent the hydroxyl group at C-7 is equatorial and therefore in $\beta$-orientation. Therefore its NMR data were in good accordance to those of the close related $3 \beta, 7 \beta$-dihydroxyandrost-5-en-17-one.

\section{$3 \beta, 7 \beta$-dihydroxypregn-5-en-20-one (7 $\beta$-OH-PREG)}

${ }^{1} \mathrm{H}$ NMR: $\left(\mathrm{CDCl}_{3}, 500 \mathrm{MHz}\right): \delta 0.63 \mathrm{~s}(3 \mathrm{H}, 3 \times \mathrm{H}-18)$, $1.03 s$ (3H, $3 \times \mathrm{H}-19), 1.06 m$ (H-1a), $1.07 m$ (H-9), 1.27 $m$ (H-14), $1.39 m$ (H-12b), $1.40 m$ (H-8), $1.47 m$ (H-11a), $1.50 m$ (H-2a), $1.56 m$ (H-15a), $1.62 m$ (H-11b), $1.70 m$ (H-16a), $1.84 m$ (2H, H-1b and H-2b), $1.92 m$ (H-15b), $2.03 m$ (H-12b), $2.11 s(3 \mathrm{H}, 3 \mathrm{x} \mathrm{H}-21), 2.18 m$ (H-16b), $2.23 m(\mathrm{H}-4 \mathrm{a}), 2.32 d d d(J=13.5,5.0$ and $2.0 \mathrm{~Hz}, \mathrm{H}-4 \mathrm{~b})$, $2.48 d d(J=9.5$ and $9.5 \mathrm{~Hz}, \mathrm{H}-17), 3.53 m(\mathrm{H}-3), 3.83$ ddd $(J=8.0,2.0$ and $2.0 \mathrm{~Hz}, \mathrm{H}-7), 5.27 d d(J=2.0$ and $2.0 \mathrm{~Hz}, \mathrm{H}-6) .{ }^{13} \mathrm{C} \mathrm{NMR}\left(\mathrm{CDCl}_{3}, 125 \mathrm{MHz}\right): \delta 13.20$ (C-18), 19.14 (C-19), 21.04 (C-11), 23.35 (C-16), 26.68 (C-15), 31.53 (C-2), 31.59 (C-21), 36.58 (C-10), 36.91 (C-1), 38.64 (C-12), 41.09 (C-8), 41.49 (C-4), 44.42 (C-13), 48.12 (C-9), 56.03 (C-14), 63.05 (C-17), 71.36 (C-3), 73.14 (C-7), 125.49 (C-6), 143.49 (C-5), 209.54 (C-20).

\section{Additional file}

Additional file 1: Figure S1. Dexamethasone conversion with $B$. megaterium ATCC13368: Dexamethasone $(200 \mu \mathrm{M})$ was added to $500 \mu \mathrm{l}$ sample of a $16 \mathrm{~h}$ culture of B. megaterium ATCC13368 wild type and cyp106a2-knockout and incubated for 60 minutes at $30^{\circ} \mathrm{C}$. Figure S2. Prednisone conversion with B. megaterium ATCC13368: Prednisone $(200 \mu \mathrm{M})$ was added to $500 \mu \mathrm{l}$ sample of a $16 \mathrm{~h}$ culture of $\mathrm{B}$. megaterium ATCC13368 wild type and cyp106a2-knockout and incubated for 60 minutes at $30^{\circ} \mathrm{C}$. Figure S3. Digitoxigenin conversion with B. megaterium ATCC13368: Digitoxigenin (200 $\mu \mathrm{M})$ was added to $500 \mu \mathrm{l}$ sample of a $16 \mathrm{~h}$ culture of B. megaterium ATCC13368 wild type and cyp106a2-knockout and incubated for 60 minutes at $30^{\circ} \mathrm{C}$. Figure S4. Conversion of DHEA with the B. megaterium MS941 strain without expression plasmid: Conversions were conducted in $50 \mathrm{mM}$ potassium-phosphate buffer adjusted to $\mathrm{pH} 7.4$, at $30^{\circ} \mathrm{C}$ and $150 \mathrm{rpm}$ in $300 \mathrm{ml}$ baffled shake flasks. 400 MM DHEA were added and samples taken at indicated time-points. No remarkable DHEA conversion was detected after 24 hours. The impurity eluting at about minute 1, is most probably a metabolite from the B. megaterium MS941 cells, independent from CYP106A2 dependent DHEA conversion. Figure S5. Selectivity of DHEA-hydroxylation with the B. megaterium ATCC13368 wild type strain compared with the B. megaterium MS941_pSMF2.1CAA overexpression strain: Conversions were performed with $24 \mathrm{~h}$ cultures of both strains for 60 minutes in $50 \mathrm{mM}$ potassium-phosphate buffer and DHEA. The amount of the respective products in percent was calculated using the peak area/min. The bars show the mean values and standard deviations from three independent conversions.

\section{Abbreviations}

P450: Cytochrome P450 enzymes; AdR: Adrenodoxin reductase; Adx: Adrenodoxin; B. megaterium: Bacillus megaterium; DHEA: Dehydroepiandrosterone; PREG: Pregnenolone; HEPES: (4-(2-hydroxyethyl)-1-piperazineethanesulfonic acid); NMR: Nuclear spin resonance; ppm: Parts per million; Rf: Retention factor; HPLC: High-performance liquid chromatography; TLC: Thin layer chromatography.

\section{Competing interests}

The authors declare that there are no competing interests.

\section{Authors' contributions}

DS carried out the biochemical and biotechnological experiments and drafted the manuscript. JZ did all NMR measurements and structure determinations of the hydroxysteroids produced in this work. RB participated in the interpretation of the results and assisted in manuscript drafting. All authors read and approved the final manuscript.

\section{Acknowledgement}

This work was supported by a grant from the Saarland Ministry of Economics and Science. The authors thank Wolfgang Reinle and Katharina Bompais for the expression and purification of $\mathrm{AdR}$ and $\mathrm{Adx}$.

\section{Author details}

'Department of Biochemistry, Saarland University, Campus B2 2, Saarbruecken 66123, Germany. '2Department of Pharmaceutical Biology, Saarland University, Campus C2 2, Saarbruecken 66123, Germany.

Received: 5 January 2014 Accepted: 13 April 2014

Published: 5 June 2014

\section{References}

1. Omura T, Sato R: The Carbonmonoxide Binding Pigment of Liver Microsomes. J Biol Chem 1964, 239:2370-2378.

2. Nelson DR: The cytochrome P450 homepage. Hum Genomics 2009, 4:59-65.

3. Podust LM, Sherman DH: Diversity of P450 enzymes in the biosynthesis of natural products. Nat Prod Rep 2012, 29:1251-1266.

4. Sono M, Roach MP, Coulter ED, Dawson JH: Heme-Containing Oxygenases. Chem Rev 1996, 96:2841-2888.

5. Bernhardt R: Cytochrome P450: structure, function, and generation of reactive oxygen species. Rev Physiol Biochem Pharmacol 1996, 127:137-221.

6. Peng Y, Yashphe J, Demain AL: Biotransformation of compactin to pravastatin by Actinomadura sp. 2966. J Antibiot 1997, 50:1032-1035.

7. Sakaki T: Practical Application of Cytochrome P450. Biol Pharm Bull 2012, 35:844-849

8. Bernhardt R: Cytochromes P450 as versatile biocatalysts. J Biotechno/ 2006 124:128-145.

9. O'Reilly E, Köhler V, Flitsch SL, Turner NJ: Cytochromes P450 as useful biocatalysts: addressing the limitations. Chem Commun 2011, 47:2490-2501.

10. Chefson A, Auclair K: Progress towards the easier use of P450 enzymes. Mol Biosyst 2006, 2:462-469.

11. Bureik M, Lisurek M, Bernhardt R: The Human Steroid Hydroxylases CYP11B1 and CYP11B2. Biol Chem 2002, 383:1537-1551.

12. Simpson $\mathrm{E}$, Brown KA: Obesity and breast cancer: role of inflammation and aromatase. J Mol Endocrinol 2013, 51(3):T51-T59.

13. Zehentgruber D, Hannemann F, Bleif S, Bernhardt R, Lütz S: Towards preparative scale steroid hydroxylation with cytochrome P450 monooxygenase CYP106A2. Chembiochem 2010, 11:713-721.

14. Berg A, Gustafsson JA, Ingelman-Sundberg M: Characterization of a cytochrome P-450-dependent steroid hydroxylase system present in Bacillus megaterium. J Biol Chem 1976, 251:2831-2838. 
15. Lisurek M, Kang M, Hartmann RW, Bernhardt R: Identification of monohydroxy progesterones produced by CYP106A2 using comparative HPLC and electrospray ionisation collision-induced dissociation mass spectrometry. Biochem Biophys Res Commun 2004, 319:677-682.

16. Kang M, Lisurek M, Bernhardt R, Hartmann RW: Use of high-performance liquid chromatography/electrospray ionization collision-induced dissociation mass spectrometry for structural identification of monohydroxylated progesterones. Rapid Commun Mass Spectrom 2004 $18: 2795-2800$

17. Bleif S, Hannemann F, Lisurek M, Kries JP, Zapp J, Dietzen M, Antes I, Bernhardt R: Identification of CYP106A2 as a regioselective allylic bacterial diterpene hydroxylase. Chembiochem 2011, 12:576-582.

18. Bleif S, Hannemann F, Zapp J, Hartmann D, Jauch J, Bernhardt R: A new Bacillus megaterium whole-cell catalyst for the hydroxylation of the pentacyclic triterpene 11-keto- $\beta$-boswellic acid (KBA) based on a recombinant cytochrome P450 system. Appl Microbiol Biotechnol 2012, 93:1135-1146.

19. Schmitz D, Zapp J, Bernhardt R: Hydroxylation of the triterpenoid dipterocarpol with CYP106A2 from Bacillus megaterium. FEBS J 2012, 279:1663-1674.

20. Lathe R: Steroid and sterol 7-hydroxylation: ancient pathways. Steroids 2002, 67:967-977.

21. Robinzon B, Michael KK, Ripp SL, Winters SJ, Prough RA: Glucocorticoids inhibit interconversion of 7-hydroxy and 7-oxo metabolites of dehydroepiandrosterone: a role for 11 beta-hydroxysteroid dehydrogenases? Arch Biochem Biophys 2003, 412:251-258.

22. Chalbot S, Morfin R: Human liver S9 fractions: metabolism of dehydroepiandrosterone, epiandrosterone, and related 7-hydroxylated derivatives. Drug Metab Dispos 2005, 33:563-569.

23. Janocha S, Bernhardt R: Design and characterization of an efficient CYP105A1-based whole-cell biocatalyst for the conversion of resin acid diterpenoids in permeabilized Escherichia coli. Appl Microbiol Biotechnol 2013, 97:7639-7649.

24. Virus $C$, Lisurek M, Simgen B, Hannemann F, Bernhardt R: Function and engineering of the 15beta-hydroxylase CYP106A2. Biochem Soc Trans 2006, 34:1215-1218.

25. Ewen KM, Ringle M, Bernhardt R: Adrenodoxin-A versatile ferredoxin. IUBMB Life 2012, 64:506-512.

26. Lisurek M: Homologie-Modellierung und Protein-Engineering der Steroid-15 $\beta$ Hydroxylase (CYP106A2) aus Bacillus megaterium. Saarbruecken: PhD-thesis Biochemistry; 2004

27. Ringle M, Khatri Y, Zapp J, Hannemann F, Bernhardt R: Application of a new versatile electron transfer system for cytochrome P450-based Escherichia coli whole-cell bioconversions. Appl Microbiol Biotechnol 2013, 97:7741-7754

28. Lisurek M, Simgen B, Antes I, Bernhardt R: Theoretical and experimental evaluation of a CYP106A2 low homology model and production of mutants with changed activity and selectivity of hydroxylation. Chembiochem 2008, 9:1439-1449.

29. Virus C, Bernhardt R: Molecular evolution of a steroid hydroxylating cytochrome P450 using a versatile steroid detection system for screening. Lipids 2008, 43:1133-1141.

30. Julsing MK, Cornelissen S, Buhler B, Schmid A: Heme-iron oxygenases: powerful industrial biocatalysts? Curr Opin Chem Biol 2008, 12:177-186.

31. Girhard M, Klaus T, Khatri Y, Bernhardt R, Urlacher VB: Characterization of the versatile monooxygenase CYP109B1 from Bacillus subtilis. Appl Microbiol Biotechnol 2010, 87:595-607

32. Brill E, Hannemann F, Zapp J, Brüning G, Jauch J, Bernhardt R: A new cytochrome P450 system from Bacillus megaterium DSM319 for the hydroxylation of 11-keto- $\beta$-boswellic acid (KBA). Appl Microbiol Biotechnol 2014, 98:1701-1717.

33. Nguyen KT, Virus C, Günnewich N, Hannemann F, Bernhardt R: Changing the regioselectivity of a P450 from $\mathrm{C} 15$ to $\mathrm{C} 11$ hydroxylation of progesterone. Chembiochem 2012, 13:1161-1166.

34. Holland H: Recent advances in applied and mechanistic aspects of the enzymatic hydroxylation of steroids by whole-cell biocatalysts. Steroids 1999, 64:178-186.

35. Kihel LE: Oxidative metabolism of dehydroepiandrosterone (DHEA) and biologically active oxygenated metabolites of DHEA and epiandrosterone (EpiA) - Recent reports. Steroids 2012, 77:10-26.
36. Li P, Brueggemeier RW: 7-Substituted 1,4,6-androstatriene-3,17-diones as enzyme-activated irreversible inhibitors of aromatase. J Steroid Biochem 1990, 36:533-539.

37. Donova MV, Egorova OV: Microbial steroid transformations: current state and prospects. Appl Microbiol Biotechnol 2012, 94:1423-1447.

38. Girhard M, Machida K, Itoh M, Schmid RD, Arisawa A, Urlacher VB: Regioselective biooxidation of (+)-valencene by recombinant E. coli expressing CYP109B1 from Bacillus subtilis in a two-liquid-phase system. Microb Cell Fact 2009, 8:36.

39. Verhoef S, Wierckx N, Westerhof RGM, de Winde JH, Ruijssenaars HJ: Bioproduction of $\mathrm{p}$-hydroxystyrene from glucose by the solvent-tolerant bacterium Pseudomonas putida S12 in a two-phase water-decanol fermentation. Appl Environ Microbiol 2009, 75:931-936.

40. Sagara Y, Wada A, Takata Y, Waterman MR, Sekimizu K, Horiuchi T: Direct expression of adrenodoxin reductase in Escherichia coli and the functional characterization. Biol Pharm Bull 1993, 16:627-630.

41. Uhlmann H, Beckert V, Schwarz D, Bernhardt R: Expression of bovine adrenodoxin in E. coli and site-directed mutagenesis of/2 Fe-2S/cluster ligands. Biochem Biophys Res Commun 1992, 188:1131-1138.

42. Jefcoate CR: Measurement of substrate and inhibitor binding to microsomal cytochrome P-450 by optical-difference spectroscopy. Methods Enzymol 1978, 52:258-279.

43. Schenkman JB, Jansson I: Spectral analyses of cytochromes P450. Meth Mol Biol (Clifton, NJ) 1998, 107:25.

44. Rauschenbach R, Isernhagen M, Noeske-Jungblut C, Boidol W, Siewert G: Cloning sequencing and expression of the gene for cytochrome P450meg, the steroid-15 $\beta$-monooxygenase from Bacillus megaterium ATCC 13368. Mol Gen Genet 1993, 241:170-176.

45. Li H, Liu H-M, Ge W, Huang L, Shan L: Synthesis of 7a-hydroxydehydroepiandrosterone and $7 \beta$-hydroxy-dehydroepiandrosterone. Steroids 2005, 70:970-973.

doi:10.1186/1475-2859-13-81

Cite this article as: Schmitz et al: Steroid conversion with CYP106A2 production of pharmaceutically interesting DHEA metabolites. Microbial Cell Factories 2014 13:81.

\section{Submit your next manuscript to BioMed Central and take full advantage of:}

- Convenient online submission

- Thorough peer review

- No space constraints or color figure charges

- Immediate publication on acceptance

- Inclusion in PubMed, CAS, Scopus and Google Scholar

- Research which is freely available for redistribution 